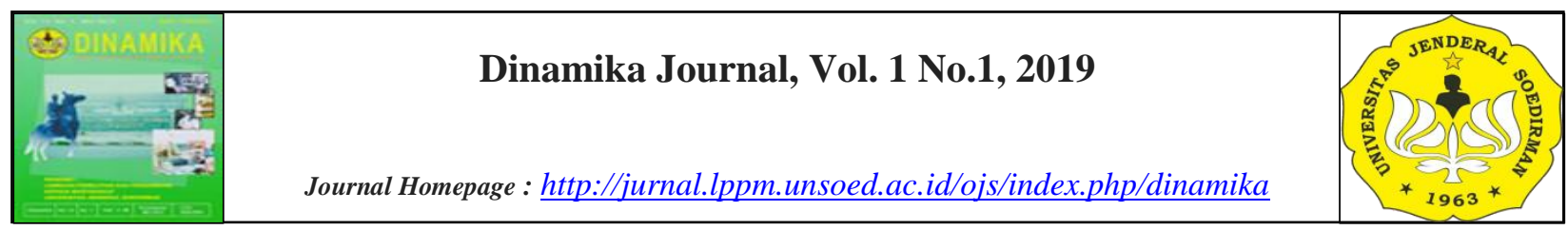

\title{
IMPLEMENTASI METODE PEMBELAJARAN BAHASA UNTUK GURU SEKOLAH DASAR
}

\author{
*M. Riyanton \\ *Fakultas Ilmu Budaya, Universitas Jenderal Soedirman \\ *Corresponding author: muhammadriyanton@gmail.com
}

Received 9 May 2019; Accepted 18 June 2019; Available online 19 June 2019

\begin{abstract}
Abstrak
Pemilihan model pembelajaran merupakan faktor penting saat proses pembelajaran. Peserta didik akan dituntut kemandirian dan tanggung jawabnya sebagai insan cendekia. Oleh karena itu, guru hendaknya dalam pembelajaran menggunakan model/strategi yang relevan. Penggunaan model pembelajaran yang tepat akan membuat siswa merasa nyaman dan dekat dengan pendidik, sehingga akan terjalin pembelajaran yang kondusif. Tujuan kegiatan ini secara umum bertujuan untuk meningkatkan kemampuan guru dalam memilih dan menerapkan model-model pembelajaran, yakni dalam mengimplementasikan model/strategi yang tepat dalam Rencana Pelaksanaan Pembelajaran (RPP) di sekolah masing-masing. Metode kegiatan ini berupa pelatihan kepada para guru-guru Sekolah Dasar di UPK Kecamatan Kedungbanteng Kabupaten Banyumas. Langkah-langkah pelatihan antara lain (1) Penyemaian informasi; (2) Pemberian model pembelajaran bahasa; (3) Praktik membuat RPP; (4) Praktik/Implementasi menyelenggarakan pembelajaran dengan menggunakan pembelajaran bahasa yang telah didesain. Hasil pengabdian masyarakat ini bahwa keterampilan guru setelah mengikuti pelatihan ini terjadi kenaikan signifikan terhadap nilai rata-rata yang diperoleh 78 dengan nilai paling rendah guru adalah 60 sedangkan paling tinggi adalah 90. Setelah posttest tulis dilakukan, hasil nilai praktik pembelajaran dengan menggunakan Circ, Jigsaw, dan STAD juga menunjukkan hasil yang memuaskan, hal ini tampak dari meningkatnya percaya diri guru ketika berbicara dalam bahasa Indonesia, interaksi yang terjadi antara guru dan siswa juga mulai bagus.
\end{abstract}

Kata Kunci: Model Pembelajaran, Kooperatif Circ, Jigsaw, dan STAD

\begin{abstract}
Learning model selection is one important factor during the teaching-learning processes. The students are expected to become independent and responsible as the scholars. Therefore, teachers should implement relevant learning models or strategies. The properly implemented learning models may comfort and make the students close to their teachers that condusive teaching-learning situations may be created. The purpose of this activity is generally to improve the teachers' capacity in selecting and implement various learning
\end{abstract}


models including implementing proper models or stategies in preparing the Lesson Plans at school. This activity employs training methods for the elementary school teachers available in The activity implementing unit (Unit Pelaksana Kegiatan known as UPK) of Kedungbanteng district, Banyumas Regency. The training stages are (1) information dissemination; (2) explaining various language learning models; (3) Lesson Plan Making Practices; (4) implementing those designed lesson plans into practices using the particularly selected language learning models. The result of this community service activity showed that the teachers' skills significatly improved after joining the trainings with the average score of 78 , the lowest score of 60, and the highest score of 90. After a written posttest, the learning practice score results after implementing Circ, Jigsaw, and STAD are considered satisfying, proven by the improving teachers' confidence when speaking to the students and better interactions between the teachers and the students.

Keywords: Learning Model, Cooperative Circ, Jigsaw, and STAD

\section{PENDAHULUAN}

Pembelajaran di sekolah berarti melakukan optimalisasi kegiatan belajar mengajar (KBM), yang didukung oleh lingkungan pendidikan. Dalam pengertian ini, optimalisasi KBM mengacu pada dinamika penjabaran komponen-komponen dalam KBM. Komponen tersebut perlu terus dikembangkan secara dinamis dengan memperhatikan kepentingan dan kekhasan daerah serta perkembangan ipteks. Isi pendidikan secara terus-menerus dikembangkan secara serasi dan seimbang agar tercapai tujuan pendidikan yang diinginkan.

Untuk mencapai tujuan pembelajaran aktif, kreatif, efektif, dan menyenangkan (PAKEM) tentunya perlu mengetahui beberapa hal penting sebagai faktor penunjangnya. Fungsi pembelajaran sekolah adalah sebagai pembinaan kesatuan dan persatuan bangsa, sarana peningkatan keterampilan dan pengetahuan meraih ilmu dan teknologi, peningkatan kemampuan dan keterampilan untuk pelestarian dan pengembangan budaya, saran pengembangan penalaran dan penyebarluasan dalam menyangkut berbagai masalah.

Untuk meningkatkan kualitas pembelajaran di sekolah dapat kita jabarkan dalam beberapa komponen. Komponen-komponen inti pembelajaran antara lain; merumuskan tujuan pembelajaran, guru, siswa, model-model pembelajaran, dan evaluasi. Akan tetapi, yang menjadi kunci tercapainya pembelajaran di kelas ialah guru. Guru harus mampu menjadi fasilitator saat pembelajaran dengan memilih metode/model pembelajaran yang komunikatif dan efektif.

Dalam proses belajar mengajar, guru sebagai komponen pendidikan yang pertama dan utama harus mampu memberikan yang terbaik pada siswa. Guru tidak hanya berperan sebagai sumber penyampaian ilmu saja, tetapi guru mampu memberikan perhatian secara psikologis pada siswa. Interaksi antara guru dan siswa akan terjadi jika pembelajaran itu memakai ladasan yang bersifat kognitif, afektif, dan psikomotorik. Dengan tiga landasan ini tentu saja, proses pembelajaran akan berjalan dengan baik. Demikian halnya dengan guru bahasa Indonesia.

Kebebasan guru untuk mempersiapkan, melaksanakan dan mengevaluasi tehadap pembelajaran akan mempermudah dalam menyampaikan ilmu pengetahuan pada diri peserta didik. Guru selalu terbuka, untuk membantu dan memotivasi siswa dalam menemukan dan memecahkan masalah. Penguasaan kompetensi dan skiil akan tercapai jika suasana pembelajaran berjalan dengan demokratis, menyenangkan, dan terjadi perubahan perilaku pada siswa menjadi lebih baik. 
Pemilihan model pembelajaran merupakan faktor penting saat proses pembelajaran. Peserta didik akan dituntut kemandirian dan tanggung jawabnya sebagai insan cendekia. Oleh karena itu, guru hendaknya dalam pembelajaran menggunakan model/strategi yang relevan. Perubahan dan perkembangan siswa selalu dibimbing, diamati dan dikembangkan setiap pembelajaran. Dengan menggunakan model pembelajaran yang tepat siswa akan merasa nyaman dan dekat dengan pendidik, sehingga akan terjalin pembelajaran yang kondusif.

Untuk meningkatkan kualitas pembelajaran guna melakukan pembenahan kualitas pembelajaran dapat dimulai dari pemilihan model pembelajaran. Pelatihan ini akan mencoba meningkatkan kualitas pembelajaran dan pemilihan model pembelajaran yang dilakukan oleh guru. Berdasarkan hal tersebut, dapat diketahui bahwa latar belakang diadakannya pelatihan ini adalah kurangnnya kemampuan guru dalam melaksanakan pembelajaran yang kondusif dan menyenangkan di lingkungan akademika. Oleh karena itu, sebagai usaha penyelesaiannya guru perlu berpartisipasi dalam pelatihan model pembelajaran, sehingga pembelajaran akan berhasil sesuai dengan tujuan yang dirumuskan.

\section{METODE PELAKSANAAN}

Adapun tahapan dari identifiasi masalah sampai dengan dilaksanakannya kegiatan pengabdian ini mengikuti alur seperti yang digambarkan pada bagan di bawah ini:

\begin{tabular}{|c|c|c|}
\hline Tahap I & Identifikasi Permasalahan & $\begin{array}{l}\text { 1. Survei } \\
\text { 2. wawancara }\end{array}$ \\
\hline Tahap II & $\begin{array}{l}\text { Pengolahan Informasi \& Penentuan } \\
\text { Pemecahan permasalahan }\end{array}$ & $\begin{array}{ll}\text { 1. } & \text { Kajian Teoretik } \\
\text { 2. } & \text { Kajian Empirik }\end{array}$ \\
\hline Tahap III & Penyusunan materi implementasi & $\begin{array}{l}\text { 1. Mengumpulkan referensi } \\
\text { penggunaan bahasa kelas } \\
\text { 2. Penentuan ekspresi-ekspresi } \\
\text { bahasa kelas yang penting } \\
\text { 3. Pemberian Contoh } \\
\text { pembelajaran dengan } \\
\text { menggunakan bahasa kelas } \\
\text { berdasarkan model } \\
\text { Kooperatif Circ, Jigsaw, dan } \\
\text { STAD }\end{array}$ \\
\hline
\end{tabular}

\section{Tahap IV}

\begin{tabular}{|c|c|c|}
\hline \multirow[t]{5}{*}{ Implementasi } & \multirow{2}{*}{$\begin{array}{l}\text { Penyemaian informasi } \\
\text { pembelajaran hakikat } \\
\text { bahasa kelas }\end{array}$} & \multirow[t]{2}{*}{ Ceramah dan tanya jawab } \\
\hline & & \\
\hline & \multirow{2}{*}{$\begin{array}{l}\text { Penyemaian informasi } \\
\text { contoh- contoh ekspresi } \\
\text { bahasa kelas }\end{array}$} & Ceramah dan tanya jawab \\
\hline & & \\
\hline & Pemberian model & Demontrasi contoh pembelajaran \\
\hline
\end{tabular}




\begin{tabular}{|c|c|}
\hline $\begin{array}{l}\text { pembelajaran dengan } \\
\text { menggunakan bahasa kelas } \\
\text { dalam } 3 \text { fase (awal, inti, }\end{array}$ & dengan menggunakan bahasa kelas \\
\hline $\begin{array}{l}\text { Membuat contoh } \\
\text { pembelajaran dengan } \\
\text { menggunakan model } \\
\text { Kooperatif Circ, Jigsaw, dan } \\
\text { STAD }\end{array}$ & $\begin{array}{l}\text { Kerja kelompok membuat contoh } \\
\text { pembelajaran dengan menggunakan } \\
\text { model Kooperatif Circ, Jigsaw, dan } \\
\text { STAD }\end{array}$ \\
\hline $\begin{array}{l}\text { Praktik menyelenggarakan } \\
\text { pembelajaran dengan model } \\
\text { Kooperatif Circ, Jigsaw, dan } \\
\text { STAD }\end{array}$ & $\begin{array}{l}\text { Demontrasi pembelajaran dengan } \\
\text { menggunakan model Kooperatif } \\
\text { Circ, Jigsaw, dan STAD }\end{array}$ \\
\hline
\end{tabular}

\section{Bagan 1. Kerangka Pemecahan Masalah}

Metode kegiatan ini berupa pelatihan kepada para guru-guru Sekolah Dasar Di UPK Pendidkan Kecamatan Kedungbanteng Kabupaten Banyumas. Setelah diberi pelatihan, selanjutnya mereka dibimbing untuk menerapkan hasil kegiatan dalam rangka meningkatkan kemampuan Metode yang dipilih dalam melaksanakan kegiatan PPM ini adalah pelatihan terutama kepada para guru yang belum menerapkan model pembelajaran kooperatif. Oleh karena guru-guru SD sudah memiliki pengalaman mengajarkan bahasa , maka rancangan kegiatan berupa in-service training. Langkah-langkah kegiatan yang akan ditempuh adalah sebagai berikut:

1. Penyemaian informasi, berupa landasan teoretis tentang hakikat metode pembelajaran bahasa dan peranannya.

2. Pemberian model berupa pembelajaran bahasa kelas

3. Praktik membuat persiapan mengajar dengan menggunakan ekspresi-ekspresi bahasa kelas (classroom language) secara berkelompok pada fase awal, inti, dan penutup pembelajaran.

4. Praktik menyelenggarakan pembelajaran dengan menggunakan pembelajaran bahasa yang telah didesain.

\section{Metode Pelatihan}

Untuk melaksanakan kegiatan tersebut digunakan beberapa metode pelatihan, yaitu:

\section{Metode Ceramah}

Metode ceramah dipilih untuk memberikan penjelasan tentang model pembelajaran: memotivasi guru-guru agar mau membuat RPP yang berbasis model kooperatif, cara menanamkan pemahaman Guru-guru tentang teknis penulisan RPP berbasis model pembelajaran Circ, Jigsaw, dan STAD dan sangat penting untuk dikuasai oleh peserta pelatihan. 


\section{Metode Tanya Jawab}

Metode tanya jawab sangat penting bagi para peserta pelatihan, baik di saat menerima penjelasan tentang model pembelajaran kooperatif serta saat mempraktekkannya, Metode ini memungkinkan guru-guru menggali pengetahuan sebanyak-banyaknya tentang model pembelajaran Circ, Jigsaw, dan STAD.

\section{Metode Simulasi}

Metode simulasi ini sangat penting diberikan kepada para peserta pelatihan untuk memberikan desempatan mempraktikan materi pelatihan yang diperoleh. Harapannya, peserta pelatihan akan benar-benar menguasai materi pelatihan yang diterima, mengetahui tingkat kemampuannya menerapkan kegiatan model pembelajaran Circ, Jigsaw, dan STAD.

\section{HASIL DAN PEMBAHASAN}

\subsection{Hakikat Model Pembelajaran Kooperatif}

a) Pengertian Model Pembelajaran

Model pembelajaran dapat diterapkan dalam pembelajaran guna mencapai tujuan pembelajaran. Selain itu, model pembelajaran dapat diterapkan untuk mengukur efek berbagai sumber belajar dan hasil interaksinya, sehingga informasi ini kemudian dapat digunakan dalam perencanaan pembelajaran, sehingga dapat dialokasikan ke sumber belajar dengan efek untuk mempercepat proses pembelajaran. Ditegaskan oleh Chen dan Lin (2018) bahwa penggunaan model pembelajaran secara umum dapat dikatakan bahwa model merupakan gambaran mental yang bisa membantu siswa dalam memahami pembelajaran dan pengalaman langsung. Sementara itu, model dikemukakan Dewey (dalam Joyce et al.,2009:14) model pembelajaran adalah rencana atau pola yang digunakan dalam penyusunan kurikulum, mengatur materi siswa, dan memberi petunjuk kepada pengajar di dalam kelas dalam setting pengajaran atau setting lainnya. Model pembelajaran adalah kerangka konseptual yang melukiskan prosedur yang sistematis dalam mengorganisasikan pengalaman belajar untuk mencapai tujuan tertentu dan berfungsi sebagai pedoman bagi para perancang pembelajaran dan para pengajar dalam merencanakan dan melaksanakan aktivitas pembelajaran (Suryaman, 2004: 66).

Terdapat beberapa model pembelajaran yang berpijak dari paradigma berpikir dalam pendidikan yang telah dikembangkan di dunia maju. Joyce et al., (2009: 23-28) mengelompokkan model pembelajaran ini minimal ada empat kelompok yang mendasar, yaitu: (1) model pemrosesan informasi (information processing family model), (2) model pribadi (personal family model), (3) model interaksi sosial (social family model, dan (4) model sistem perilaku (behavioral system family model). Sementara, ahli yang lain meyebutkan minimal ada tiga jenis model mendasar, yaitu : competitive learning model, individual learning model, dan cooperative learning model (Slavin, 1995: 4-5; Anita Lie, 2008: 23). 


\section{b) Model Pembelajaran Kooperatif}

Dasar filosofis pembelajaran kooperatif ialah keyakinan bahwa bekerja sama akan menghasilkan energi kolektif yang disebut sebagai sinergi (synergy). Sinergi ini akan menghasilkan sesuatu yang luar biasa Dalam dunia pendidikan sinergi ini diaplikasikan dalam komunitas pembelajaran (Johnson \& Johnson, 1994: 21; Slavin, 1995: 16; Joyce et al., 2009: 34). Di samping dasar filosofis di atas, model pembelajaran kooperatif muncul karena adanya suatu anggapan mengenai tabiat dasar manusia sebagai makhluk sosial dan cara-cara mereka belajar. Model sosial menitikberatkan pada tabiat sosial manusia, bagaimana manusia mempelajari tingkah laku sosial, dan bagaimana interaksi sosial ini dapat meningkatkan hasil capaian pembelajaran. Dalam aplikasinya model pembelajaran kooperatif dilandasi tujuan-tujuan dan asumsi-asumsi sebagai berikut. (1) Sinergi yang ditingkatkan dalam bentuk kerja sama akan meningkatkan motivasi yang jauh lebih besar daripada dalam bentuk lingkungan kompetisi individual. Kelompok-kelompok sosial integratif memiliki pengaruh yang lebih besar daripada kelompok yang dibentuk secara berpasangan. Perasaan-perasaan saling berhubungan (feelings of connectedness) menghasilkan energi yang positif; (2) Anggota-anggota kelompok kooperatif dapat saling belajar satu dengan lainnya. Setiap pembelajar akan memiliki bantuan yang lebih banyak daripada dalam sebuah struktur pembelajaran yang menimbulkan pengucilan antarsatu siswa dengan siswa lainnya;(3) Interaksi antaranggota akan menghasilkan aspek kognitif, semisal kompleksitas;(4) Kerja sama meningkatkan perasaan positif satu dengan lainnya, menghilangkan penyendirian, membangun sebuah hubungan, dan memberikan pandangan positif terhadap orang lain; (5) Kerja sama meningkatkan penghargaan diri, tidak hanya pembelajaran yang terus berkembang tetapi juga melalui perasaan dihormati dan dihargai oleh orang lain dalam sebuah lingkungan; (6) Siswa yang mengalami dan menjalani tugas, merasa harus bekerja sama sehingga dapat meningkatkan kapasitasnya untuk bekerja sama secara produktif; (7) Siswa dapat belajar dari beberapa latihan untuk meningkatkan kemampuan mereka untuk bekerja sama (Joyce et al., 2009: 302). Lebih lanjut dijelaskan manfaat dan kelebihan metodologi ini telah banyak diteliti. Menunjukkan menunjuk ke manfaat dari metode kooperatif menunjukkan dampak positif terkait kinerja dan sikap siswa dan guru, dibandingkan dengan metodologi yang lebih formal atau tradisional seperti metode instruksi langsung (Saborit et al., 2016).

Berpijak dari asumsi-asumsi di atas, pembelajaran kooperatif dapat dikatakan sebagai pembelajaran dalam bentuk kelompok siswa yang memerlukan saling ketergantungan positif, akuntabilitas individu, memiliki keterampilan interpersonal, tatap muka interaksi promotif, dan pengolahan kelompok (Johnson \& Johnson, 2006). Dalam pembelajaran kooperatif, siswa memerlukan ketergantungan positif dikandung maksud bahwa dalam belajar kelompok siswa yang satu dengan lainnya saling membutuhkan, keberhasilan anggota yang satu juga keberhasilan yang lain. Terdapat akuntabilitas individu, mempunyai makna bahwa tiap-tiap anggota kelompok memiliki kontribusi belajar dalam kelompok, tidak ada satu pun anggota kelompok yang tidak memiliki andil dalam kelompok. Keterampilaan interpersonal bercirikan dalam kelompok harus terjadi komunikasi, kepercayaan, kepemimpinan, pengambilan keputusan, dan resonansi konflik. Adanya tatap muka interaktif promotif adalah kerja kelompok dilakukan secara langsung dengan tatap muka dan saling menjelaskan satu dengan lainnya. Sedangkan pengolahan kelompok adalah merefleksikan seberapa baik tim berfungsi dan bagaimana fungsi dapat semakin ditingkatkan. 


\subsection{Model Pembelajaran Kooperatif Cooperative Integrated Reading and Composition (CIRC)}

a) Konsep Model Pembelajaran Kooperatif $C I R C$

Model pembelajaran kooperatif CIRC adalah model kooperatif yang khusus dibuat untuk pembelajaran bahasa. Hal ini sesuai dengan namanya yang merupakan program komprehensif untuk mengajarkan membaca dan menulis pada kelas sekolah dasar, di samping sekolah yang lebih tinggi (Slavin, 1995: 16). Oleh karena bersifat integratif, maka dalam aplikasinya selalu mengaitkan kedua jenis keterampilan berbahasa tersebut.

b) Paradigma Model Pembelajaran Kooperatif $C I R C$

Paradigma pembelajaran kooperatif CIRC dilandasi oleh beberapa pemikiran berikut ini.

(1) Landasan Filosofis. Keyakinan bahwa bekerja sama akan menghasilkan energi kolektif yang disebut sebagai sinergi (synergy).

(2) Model pembelajaran ini dilandasi oleh asumsi-asumsi: (1) Sinergi yang ditingkatkan dalam bentuk kerja sama akan meningkatkan motivasi yang jauh lebih besar daripada dalam bentuk lingkungan kompetisi individual; (2) Anggota- anggota kelompok kooperatif dapat saling belajar satu dengan lainnya. Setiap pembelajar akan memiliki bantuan yang lebih banyak daripada dalam sebuah struktur pembelajaran yang menimbulkan pengucilan antarsatu siswa dengan siswa lainnya; (3) Interaksi antaranggota akan menghasilkan aspek kognitif, kompleksitas; (4) Kerja sama meningkatkan perasaan positif satu dengan lainnya, menghilangkan penyendirian, membangun sebuah hubungan, dan memberikan pandangan positif terhadap orang lain; (5) Kerja sama meningkatkan penghargaan diri, tidak hanya pembelajaran yang terus berkembang tetapi juga melalui perasaan dihormati dan dihargai oleh orang lain dalam sebuah lingkungan; (6) Siswa yang mengalami dan menjalani tugas, merasa harus bekerja sama sehingga dapat meningkatkan kapasitasnya untuk bekerja sama secara produktif; (7) Siswa dapat belajar dari beberapa latihan untuk meningkatkan kemampuan mereka untuk bekerja sama (Joyce et al., 2009: 302)

\subsection{Model Pembelajaran Kooperatif Jigsaw}

a) Konsep Model Pembelajaran Jigsaw

Model pembelajaran kooperatif tipe jigsaw adalah satu tipe pembelajaran kooperatif yang terdiri dari beberapa anggota dalam satu kelompok yang bertanggung jawab atas penguasaan bagian materi belajar dan mampu mengajarkan bagian tersebut kepada anggota lain dalam kelompoknya (Arend, 1997:73).

Jigsaw menggabungkan konsep pengajaran pada teman sekelompok atau teman sebaya dalam usaha membantu belajar sesamanya. Jigsaw didesain untuk meningkatkan rasa tanggung jawab untuk pembelajarannya sendiri dan juga pembelajaran orang lain.

b) Paradigma Model Pembelajaran Kooperatif Jigsaw

Paradigma pembelajaran kooperatif Jigsaw dilandasi oleh beberapa pemikiran berikut ini.

(1)Landasan Filosofis. Keyakinan bahwa bekerja sama akan menghasilkan energi kolektif yang disebut sebagai sinergi (synergy). Sinergi ini akan menghasilkan sesuatu yang luar biasa Dalam dunia pendidikan sinergi ini diaplikasikan dalam komunitas pembela-jaran (Johnson \& 
Johnson, 1994: 21; Slavin, 1995: 16; Joyce et al., 2009: 34).

(2)Asumsi-asumsi. Model pembelajaran ini dilandasi oleh asumsi-asumsi: (1) Sinergi yang ditingkatkan dalam bentuk kerja sama akan meningkatkan motivasi yang jauh lebih besar daripada dalam bentuk lingkungan kompetisi individual; (2) Anggota- anggota kelompok kooperatif dapat saling belajar satu dengan lainnya. Setiap pembelajar akan memiliki bantuan yang lebih banyak daripada dalam sebuah struktur pembelajaran yang menimbulkan pengucilan antarsatu siswa dengan siswa lainnya; (3) Interaksi antaranggota akan menghasilkan aspek kognitif, semisal kompleksitas; (4) Kerja sama meningkatkan perasaan positif satu dengan lainnya, menghilangkan penyendirian, membangun sebuah hubungan, dan memberikan pandangan positif terhadap orang lain; (5) Kerja sama meningkatkan penghargaan diri, tidak hanya pembelajaran yang terus berkembang tetapi juga melalui perasaan dihormati dan dihargai oleh orang lain dalam sebuah lingkungan; (6) Siswa yang mengalami dan menjalani tugas, merasa harus bekerja sama sehingga dapat meningkatkan kapasitasnya untuk bekerja sama secara produktif; (7) Siswa dapat belajar dari beberapa latihan untuk meningkatkan kemampuan mereka untuk bekerja sama (Joyce et al., 2009: 302).

\subsection{Model Pembelajaran Koooperatif Student Teams Achievement Division (STAD)}

a) Konsep Dasar Model Pembelajaran Koopertif STAD

Model pembelajaran kooperatif jenis STAD merupakan salah satu model pembelajaran kooperatif yang paling sederhana dan merupakan model yang paling banyak dipakai oleh guru di dunia maju, dan telah digunakan mulai dari kelas dua sampai kelas sebelas (Slavin, 1995: 143). STAD terdiri atas lima komponen utama, yaitu presentasi kelas, tim (kelompok), kuis/pertanyaan, skor kemajuan individu, dan rekognisi tim/kelompok.

Secara bersama-sama, ketiga model pembelajaran kooperatif: CIRC, Jigsaw, dan STAD dalam pembelajaran dapat dijelaskan Slavin (2015) sebagai berikut.

\begin{tabular}{|c|l|l|l|}
\hline Langkah & \multicolumn{1}{|c|}{ CIRC } & \multicolumn{1}{|c|}{ JIGSAW } & \multicolumn{1}{|c|}{ STAD } \\
\hline 1. & $\begin{array}{l}\text { Membentuk kelompok } \\
\text { dengan anggota 4-5 } \\
\text { anak secara heterogen }\end{array}$ & $\begin{array}{l}\text { Membentuk kelompok dengan } \\
\text { anggota 4-5 } \\
\text { anak secara heterogen (home } \\
\text { teams) }\end{array}$ & $\begin{array}{l}\text { Membentuk } \\
\text { dengan } \\
\text { anggota 4-5 anak secara } \\
\text { heterogen }\end{array}$ \\
\hline 2. & $\begin{array}{l}\text { Pengenalan topik yang } \\
\text { akan dibahas }\end{array}$ & $\begin{array}{l}\text { Pengenalan topik yang akan } \\
\text { dibahas }\end{array}$ & $\begin{array}{l}\text { Pengenalan topik yang akan } \\
\text { dibahas }\end{array}$ \\
\hline 3. & $\begin{array}{l}\text { Guru memberikan teks/ } \\
\text { kliping sesuai } \\
\text { dengan } \\
\text { pembelajaran. }\end{array}$ & $\begin{array}{l}\text { Guru membagikan materi } \\
\text { kepada kelompok } \\
\text { dan anggota kelompok dengan } \\
\text { materi yang berbeda }\end{array}$ & Guru menyajikan pelajaran \\
\hline
\end{tabular}




\begin{tabular}{|c|c|c|c|}
\hline 4. & $\begin{array}{l}\text { Siswa bekerja sama dan } \\
\text { berdiskusi, saling } \\
\text { membacakan, mene-mukan } \\
\text { ide pokok, dan memberi } \\
\text { tanggapan ter-hadap } \\
\text { teks/kliping. } \\
\text { kegiatan di samping dibaca } \\
\text { juga harus ditulis secara } \\
\begin{array}{l}\text { sistematis pada lembar } \\
\text { kertas }\end{array}\end{array}$ & $\begin{array}{l}\text { Setiap anggota kelompok } \\
\text { dibagi menjadi ahli } \\
\text { subtopik untuk mempelajari } \\
\text { materi secara mendalam dan } \\
\text { bertanggung jawab materi } \\
\text { bagian masing-masing. Setiap } \\
\text { kelompok di kelas itu } \\
\text { memiliki anggota yang ahli } \\
\text { (expert di bidang tertentu, } \\
\text { berdiskusi dengan anggota } \\
\text { kelompok lain yang memiliki } \\
\text { keahlian sama } \\
\text { dan membentuk kelompok } \\
\text { baru (expert teams) }\end{array}$ & $\begin{array}{l}\text { Guru memberikan tugas } \\
\text { kepada } \\
\text { kelompok untuk dikerjakan } \\
\text { anggota-anggota kelompok, } \\
\text { anggota kelompok yang } \\
\text { kesulitan dapat dijelaskan } \\
\text { anggota kelompok lain yang } \\
\text { sudah mengerti, sampai } \\
\text { semua anggota kelompok itu } \\
\text { mengerti semuanya }\end{array}$ \\
\hline 5. & $\begin{array}{l}\text { Setiap kelompok } \\
\text { mempresentasikan hasil } \\
\text { diskusi kelom-poknya } \\
\text { kepada kelompok lain. } \\
\text { Kel-ompok lain bisa } \\
\text { bertanya kepada } \\
\text { kelompok yang tampil, } \\
\text { dan anggota kelompok } \\
\text { yang tampil menjawab } \\
\text { secara bergantian. }\end{array}$ & $\begin{array}{l}\text { Setelah materi terkuasai oleh } \\
\text { semua anggota } \\
\text { kelompok ahli, semua anggota } \\
\text { ahli kembali ke kelompok asal } \\
\text { untuk menjelaskan (secara } \\
\text { bergantian) materi bagian } \\
\text { kelompok ahli kepada anggota } \\
\text { kelompok asal lainnya. }\end{array}$ & 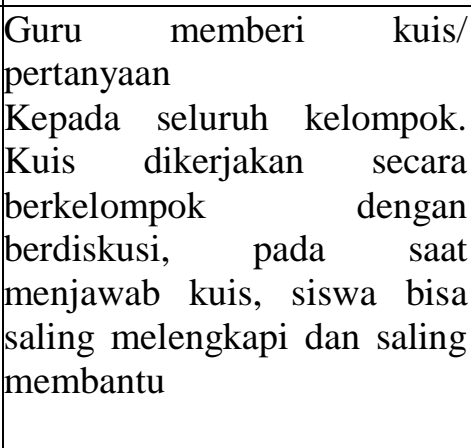 \\
\hline 6. & $\begin{array}{l}\text { Guru memberi kuis kepada } \\
\text { seluruh kelompok. Kuis } \\
\text { dikerjakan secara } \\
\text { berkelompok dengan } \\
\text { berdiskusi, pada saat } \\
\text { menjawab kuis, siswa bisa } \\
\text { saling melengkapi dan } \\
\text { saling membantu }\end{array}$ & $\begin{array}{lr}\text { Guru } & \text { memberi } \\
\text { kuis/pertanyaan kepada } & \\
\text { seluruh kelompok. } & \text { Kuis } \\
\text { dikerjakan } & \text { secara } \\
\text { berkelompok } & \text { dengan } \\
\text { berdiskusi, pada } & \text { saat } \\
\text { menjawab kuis, siswa bisa } \\
\text { saling melengkapi dan saling } \\
\text { membantu }\end{array}$ & $\begin{array}{l}\text { Guru memberikan } \\
\text { penghargaan atas } \\
\text { jaawaban kelompok }\end{array}$ \\
\hline 7. & $\begin{array}{l}\text { Guru memberika } \\
\text { penghargaan atas } \\
\text { penampilan kelompok da } \\
\text { kuis kelompok }\end{array}$ & $\begin{array}{l}\text { Guru memberikan } \\
\text { penghargaan hasil kuis } \\
\text { kelompok. }\end{array}$ & $\begin{array}{l}\text { Guru memberikan } \\
\text { bersifat individu }\end{array}$ \\
\hline 8. & $\begin{array}{l}\text { Guru memberikan kuis } \\
\text { bersifat individu }\end{array}$ & $\begin{array}{l}\text { Guru memberikan kuis } \\
\text { bersifat individu }\end{array}$ & $\begin{array}{l}\text { Evaluasi pembelajaran dan } \\
\text { simpulan }\end{array}$ \\
\hline 9. & $\begin{array}{l}\text { Guru dan siswa membuat } \\
\text { simpulan } \\
\text { bersama secara tertulis }\end{array}$ & $\begin{array}{l}\text { Guru dan siswa mengambil } \\
\text { simpulan }\end{array}$ & Penutup \\
\hline 10. & Penutup & Penutup & Penutup \\
\hline
\end{tabular}


Kegiatan pengabdian pada masyarakat yang dilakukan ini secara teknis melibatkan kerjasama antara instansi/lembaga Universitas Jenderal Soedirman dalam hal ini adalah Lembaga Pengabdian pada Masyarakat beserta tim pelaksananya, Jurusan Pendidikan Bahasa dan Sastra Indonesia, dan para Guru-guru Sekolah Dasar di UPK Pengelola SD Kecamatan Kedungbanteng Kabupaten Banyumas.

Keberadaan Lembaga Pengabdian pada Masyarakat dan Jurusan Pendidikan Bahasa dan Sastra Indonesia Unsoed, didukung oleh sumber daya manusia yang bermutu dan profesional sesuai dengan bidangnya, serta sarana prasarana yang lengkap dan memadai untuk mendukung kegiatan pelatihan dalam rangka penerapan IPTEKS. Beberapa hal yang berkaitan dengan sumber daya manusia serta sarana dan prasarana Lembaga Pengabdian Masyarakat dan Jurusan Pendidikan Bahasa dan Sastra Indonesia Unsoed adalah sebagai berikut:

1. Memiliki ruang sidang atau ruang kelas untuk penataran/pelatihan teori.

2. Memiliki dosen yang profesional dan berpengalaman dalam menghasilkan berbagai jenis karya tulis ilmiah yang bermutu.

3. Memiliki dosen yang profesional dan berpengalaman dalam pelaksanaan kegiatan penataran dan pelatihan.

Potensi yang dimiliki oleh para Guru-guru Sekolah Dasar di UPK Pengelola SD Kecamatan Kedungbanteng Kabupaten Banyumas adalah kemauan dan kemampuan yang kuat untuk mendapatkan pelatihan dan pembinaan tentang penerapan model pembelajaran yang kooperatif dalam rangka meningkatkan mutu sekolah dan profesionalisme Guru-guru.

Berdasarkan beberapa critical point yang ada di masing-masing pihak yang terkait dalam kegiatan pelatihan ini, maka bentuk kerjasama ini diharapkan akan menghadirkan sinergisme yang amat strategis dan positif antara lembaga perguruan tinggi dengan para guru-guru SD. Guru SD akan mendapatkan pelatihan dari tenaga edukatif terlatih profesional perguruan tinggi untuk meningkatkan kompetensinya dalam pembelajaran bahasa di SD dan wahana strategis untuk menyebarluaskan untuk menyebarkan ilmu pengetahuan pendidikan dengan sasaran dan jangkauan yang lebih luas yaitu kepada Guruguru Sekolah Dasar di UPK Kecamatan Kedungbanteng Kabupaten Banyumas yang keberadaanya merupakan pihak eksternal perguruan tinggi. Melalui kegiatan ini, perguruan tinggi ikut berperan nyata dalam upaya meningkatkan guru-guru dalam kegiatan PPM berbasis model pembelajaran Circ, Jigsaw, dan STAD.

Selain guru-guru yang menjadi khalayak sasaran utama dari pelaksanaan PPM ini, beberapa pihak terkait turut diundang, yaitu (1) Kepala UPK Pendidikan Kecamatan Kedungbanteng Banyumas, (2) Pengawas Sekolah, (3) Para Kepala Sekolah, dan yang menjadi penanggung jawab penuh dalam pelaksanaan Tri Dhrama Perguruan Tinggi, khususnya PPM. Tabel di bawah mendeskripsikan peran dari pihak-pihak terkait.

Evaluasi kegiatan dilakukan selama proses dan akhir pelatihan, pada aspek pencapaian tujuan pelatihan dan juga penyelenggaraan pelatihan. Evaluasi proses dan keberhasilan program pelaksanaan pengabdian masyarakat dievaluasi dengan pengamatan langsung (observation). Adapun indikator keberhasilan kegiatan adalah: 


\begin{tabular}{|c|l|l|}
\hline No. & \multicolumn{1}{|c|}{ Indikator } & Cara Pengukuran \\
\hline 1. & $\begin{array}{l}\text { Pengetahuan metode dan keterampilan } \\
\text { menggunakan bahasa }\end{array}$ & Pengetahuan \\
\hline 2. & $\begin{array}{l}\text { Mendesain pembelajaran dengan menggunakan } \\
\text { model pembelajaran Circ, Jigsaw, dan STAD }\end{array}$ & $\begin{array}{l}\text { Produk contoh desain/RPP } \\
\text { pembelajaran dengan model } \\
\text { pembelajaran Circ, Jigsaw, } \\
\text { dan STAD }\end{array}$ \\
\hline 3. & $\begin{array}{l}\text { Melaksanakan pembelajaran dengan } \\
\text { menggunakan model pembelajaran Circ, Jigsaw, } \\
\text { dan STAD }\end{array}$ & $\begin{array}{l}\text { Performansi guru dalam } \\
\text { melaksanakan } \\
\text { pembelajaran } \\
\text { menggunakan model } \\
\text { pembelajaran Circ, }\end{array}$ \\
\hline
\end{tabular}

Pertama, pembelajaran bahasa harus mengetahui prinsip-prinsip belajar bahasa yang kemudian diwujudkan dalam kegiatan pembelajarannya, serta menjadikan aspek-aspek tersebut sebagai petunjuk dalam kegiatan pembelajarannya. Prinsip-prinsip belajar bahasa dapat disarikan sebagai berikut. Pebelajar akan belajar bahasa dengan baik bila (1) diperlakukan sebagai individu yang memiliki kebutuhan dan minat, (2) diberi kesempatan berapstisipasi dalam penggunaan bahasa secara komunikatif dalam berbagai macam aktivitas, (3) bila ia secara sengaja memfokuskan pembelajarannya kepada bentuk, keterampilan, dan strategi untuk mendukung proses pemerolehan bahasa, (4) ia disebarkan dalam data sosiokultural dan pengalaman langsung dengan budaya menjadi bagian dari bahasa sasaran, (5) jika menyadari akan peran dan hakikat bahasa dan budaya, (6) jika diberi umpan balik yang tepat menyangkut kemajuan mereka, dan (7) jika diberi kesempatan untuk mengatur pembelajaran mereka sendiri. Seperti sudah dijelaskan pada bagian latar belakang masalah, meningkatkan kemampuan bahasa siswa bukan hal mudah ditengah menjamurnya kebiasaan menangkap informasi lewat media visual seperti menonton televisi atau menyimak informasi lewat radio. Diperlukan cara-cara khusus yang dapat membantu siswa dengan mudah memahami informasi yang dibaca. Pemahaman dan penguasaan guru mengiplementasikan berbagai model pembelajaran bahasa sangat bermanfaat untuk memotivasi siswa guna meningkatkan minat dan kemampuan berbahasa. Dalam penyemaian informasi mengenai metode pembelajaran bahasa di Sekolah Dasar sudah dapat dipahami oleh sebagian besar peserta yang hadir dalam pelatihan ini hanya saja yang menjadi kendala dalam penerapannya pada pembelajaran yang masih membutuhkan waktu.

Kedua, mendesain pembelajaran dengan menggunakan model pembelajaran Circ, Jigsaw, dan STAD. Pelaksanaan pengabdian masyarakat dibagi menjadi 2 tahap, pemberian materi dan pemahaman lalu presentasi dan simulasi hasil pembuatan rancangan pembelajaran dengan Circ, Jigsaw, dan STAD. Pada tahap pertama, tim pengabdian masyarakat memberikan materi dan pemahaman. Materi pendahuluan terkait karakteristik Kurikulum 2013. Dengan pemberian materi terkait Kurikulum 2013 ini, peserta pelatihan diharapkan memiliki pondasi yang kuat untuk mengembangkan kompetensinya dalam menyajikan pembelajaran yang baik dan menarik. Tim pengabdian masyarakat memberikan pemahaman tentang pendekatan yang digunakan dalam Kurikulum 2013. Pendekatan pembelajaran inilah yang akan mempengaruhi kegiatan belajar-mengajar. Berbeda dengan 
KTSP, Kurikulum 2013 secara jelas disebutkan bahwa pendekatan yang dipakai dalam pembelajaran merupakan pendekatan tematik dan saintifik. Pendekatan ini harus diserasikan dengan metode dan model pembelajarannya. Berdasarkan pertimbangan tersebut, Tim Pengabdian masyarakat memberikan pemahaman mengenai pentingnya mempersiapkan pembelajaran bahasa Indonesia dengan perencanaan yang baik. Peserta pelatihan dapat mempersiapkan pembelajaran bahasa Indonesia dengan perencanaan yang baik, maka harus memperhatikan komponen-komponen pembelajaran. Dengan kata lain, pembelajaran matematika yang baik tidak hanya terkait materi yang disajikan saja, tetapi proses penyajian juga turut mempengaruhi. Mengenai proses penyajian materi dalam pembelajaran, Tim Pengabdian masyarakat memberikan pengetahuan tentang model-model dan metode-metode yang sesuai dengan Kurikulum 2013 khususnya Circ, Jigsaw, dan STAD.

Ketiga, melaksanakan pembelajaran dengan menggunakan model pembelajaran Circ, Jigsaw, dan STAD Sebelum pelatihan dilaksanakan panitia pelaksana memandang perlu terlebih dahulu mengetahui kondisi kemampuan awal peserta pada ketiga aspek tersebut. Untuk itu dilakukan pretes, yaitu data yang dihasilkan menunjukkan nilai rata-rata peserta dalam menentukan metode yang tepat adalah 55 dengan nilai maksimum yang diperoleh sebesar 75, sedangkan nilai minimumnya sebesar 40. Berdasarkan data di atas tampak bahwa para peserta belum memiliki pengetahuan yang cukup baik dalam menentukan dan menuliskan RPP dengan metode bahasa yang tepat dengan baik. Dari keseluruhan komponen yang ditanyakan, peserta masih belum tahu tentang metode pembelajaran bahasa Circ, Jigsaw, dan STAD yang sesuai ketika proses pembelajaran sedang berlangsung, dan sebagian besar dapat menentukan atau menuliskan Circ, Jigsaw, dan STAD. Data hasil pretes menegaskan pentingnya kegiatan pelatihan metode pembelajaran bahasa berbasis Circ, Jigsaw, dan STAD untuk guru-guru SD di kecamatan Kedungbanteng. Setelah pelaksanaan pelatihan, tes kembali dilakukan (posttest) untuk melihat perkembangan keterampilan guru sekaligus menilai efektivitas dari program pelatihan. Hasilnya menunjukkan data keterampilan guru, setelah mengikuti pelatihan ini terjadi kenaikan signifikan terhadap nilai rata-rata yang diperoleh 78 dengan nilai paling rendah guru adalah 60 sedangkan paling tinggi adalah 90. Setelah posttest tulis dilakukan, hasil nilai praktik pembelajaran dengan menggunakan Circ, Jigsaw, dan STAD juga menunjukkan hasil yang memuaskan, hal ini tampak dari meningkatnya percaya diri guru ketika berbicara dalam bahasa Indonesia serta interaksi yang terjadi antara guru dengan siswa juga mulai bagus.

\section{KESIMPULAN}

Kegiatan pelatihan model-model pembelajaran bahasa telah terlaksana dengan baik dan sangat bermanfaat bagi peserta maupun bagi Program Studi Pendidikan Bahasa Indonesia sebagai lembaga penyelenggara. Para peserta mendapatkan manfaat berupa pengetahuan pemilihan dan penerapan model-model pembelajaran saat akan merencanakan (RPP) maupun saat pembelajaran. Untuk Program Studi Pendidikan Bahasa Indonesia sebagai pihak penyelenggara pelatihan ini memberikan keuntungan berupa bertambahnya citra positif Program Studi Pendidikan Bahasa Indonesia di kalangan masyarakat. Pelatihan ini juga telah memberikan manfaat yang besar dalam mempublikasikan Program Studi Pendidikan Bahasa Indonesia di kalangan masyarakat, sehingga ke depan citra masyarakat belajar di Program Studi Pendidikan Bahasa Indonesia tidak hanya belajar bahasa, tetapi juga belajar berbagai metode mengajar di sekolah. 


\section{DAFTAR PUSTAKA}

Arends, R.I. 1997. Classroom Instruction and Management. Central Conecticut State University: the McGrowHill Companies.

Chen, Tin-Chih Toly., Lin, Chi-Wei. 2018. An innovative yield learning model considering multiple learning sources and learning source interactions. Computers \& Industrial Engineering. pp 352-360

Johnson, R.T., D.W. Johnson. 1994. An Overview of Cooperative Learning. Dalam J. Thousand, A. Villa dan A. Nevin (Ed). Creativity and Collaborative Learning. Baltimore: Brookes Press.

Johnson, R.T., Johnson, D.W. 2006. What is Cooperative Learning? Minneapolis, Minnesota: The Cooperative Learning Center at the University of Minnesota.

Joyce, B., Weil, M., Calhoun, E. 2009. Models of Teaching. USA: Library of Congress Cataloging-in- Publication Data.

Lie, Anita. 2008. Metode Pembelajaran Gotong Royong. Surabaya: Universitas Kristen Petra.

Saborit, J. A. P., Rio J. F., Estrada, J. A. C., Gimenez, A. M., Alonso, D. M. 2016. Teachers' attitude and perception towards cooperative learning implementation: Influence of continuing training. Teaching and Teacher Education. pp 438-455.

Slavin, Robert E. 1995. Cooperative Learning Second Edition. Boston. Allin and Bacon.

2015. Cooperative Learning in Schools. International Encyclopedia of the Social \& Behavioral Sciences (Second Edition). pp 881-886.

Suryaman. 2004. Penerapan Model Pembelajaran Suatu Inovasi di Perguruan Tinggi (Tantangan Umum Pendidikan Tinggi). Jurnal Pendidikan IKIP PGRI Madiun. Vol. 10, No. 1, Juni, pp. 1-14. 